\title{
Technical evaluation for the proposal of a different cricondentherm limit for the Caribbean coast within Colombian gas quality regulations ${ }^{1}$
}

\section{Evaluación técnica para la propuesta de un límite diferente en la cricondenterma para la costa caribe dentro de la regulación colombiana de gas ${ }^{2}$}

\author{
Ingrid Navarro Ochoa ${ }^{3}$ \\ Manuel Figueredo Medina ${ }^{45}$
}

How to cite this article:

I. Navarro-0choa, M. Figueredo-Medina, "Technical evaluation for the proposal of a different cricondentherm limit for the Caribbean coast within Colombian gas quality regulations," Ing. Univ., vol. 22, no. 2, 2018. [0nline] https://doi.org/10.11144/Javeriana.iyu22-2.dclc

\footnotetext{
${ }^{1}$ Submitted on: February $14^{\text {th }}, 2017$. Accepted on: April $2^{\text {nd }}, 2018$. This paper is based on the research project "Estudio técnico para la inclusión de un gas nuevo cricondentherm para el transporte y entrega de gas natural en climas cálidos en Colombia en el actual reglamento de transporte", which was developed as part of the Master's program in Design and Process Management specializing in Chemical Processes at La Sabana University, Bogota, Colombia.

${ }^{2}$ Fecha de recepción: 14 de febrero de 2017. Fecha de aceptación: 2 de abril de 2018. Este artículo se deriva de un proyecto de investigación denominado "Estudio técnico para la inclusión de un gas nuevo cricondentherm para el transporte y entrega de gas natural en climas cálidos en Colombia en el actual reglamento de transporte", desarrollado por el grupo de investigación Energía, Materiales y Ambiente (GEMA) de la Universidad de La Sabana, Chía, Colombia.

3 Ingeniera Química. Maestría en Diseño y Gestión de Procesos. Facultad de Ingeniería, Universidad de La Sabana, Campus Universitario del Puente del Común, Km 7 Autopista Norte de Bogotá, Chía, Colombia. Correo electrónico: ingridnaoc@unisabana.edu.co.

${ }^{4}$ Ingeniero Químico, Maestría en Ingeniería de Sistemas. Profesor Asistente programa de Ingeniería Química, Facultad de Ingeni ería, Universidad de La Sabana, Campus Universitario del Puente del Común, Km 7 Aut opista Norte de Bogotá, Chía, Colombia. Correo Electrónico:manuelfm@unisabana.edu.co.

${ }^{5}$ Corresponding Author, email: manuelfm@unisabana.edu.co
} 


\section{Abstract}

Introduction: The cricondentherm is the highest temperature above which a liquid cannot be formed, regardless of the pressure. According to the Colombian natural gas transmission regulations, this temperature should not exceed $7.2^{\circ} \mathrm{C}$. Although this restriction is currently applied over the whole country, it is possible to propose a differe nt limit on the cricondentherm for the Colombian Caribbean coast. Methods: In this document, the current hydrocarbon dew point (HCDP) limits for gas transport pipelines in several countries worldwide are analyzed, the weather conditions on the Colombian Caribbean coast are reviewed, and a thermodynamic and hydraulic study is developed, taking into account the composition of the gas (before any treatment) from three fields on the Caribbean coast, the elevation profile of one of the gas pipelines on the Caribbean coast, and the influence of the weather conditions on the behavior of gas in the pipeline. Results: Some countries define their HCDP values depending on the region through which the gas is transported. Simulations of the chosen gas pipeline with lean gases without any treatment at the worst ambient conditions of the Colombian Caribbean coast show that there is a slight liquid condensation at $21^{\circ} \mathrm{C}$, indicating a gap with the current regulations $\left(7.2^{\circ} \mathrm{C}\right)$ in which an additional maximum cricondentherm can be proposed for the Colombian Caribbean coast. Conclusions: From this work, it is concluded that a new cricondentherm for warm climates in Colombia, within the transmission regulations, should be between 10 and $12.6^{\circ} \mathrm{C}$. This proposal is based on the results obtained in simulations and the acknowledgment that some of the Colombian gas pipelines operate only in warm regions of the country.

Keywords: Cricondentherm; natural gas; gas pipeline; colombian regulation; simulation.

\section{Resumen}

Introducción: La cricondenterma es la temperatura más alta en la cual la fase líquida no se puede formar independientemente de la presión. De acuerdo a la regulación colombiana de transporte de gas natural, no se debe exceder los $7.2^{\circ} \mathrm{C}$. Aunque esta restricción es actualmente aplicada en todo el país, es posible proponer un límite diferente para para la costa caribe colombiana. Métodos: En este documento, se analizan los límites actuales de Punto de Rocío de Hidrocarburos (PRH) para gasoductos en varios países del mundo, se revisan las condiciones climáticas de la costa caribe colombiana, y se desarrolla un estudio termodinámico e hidráulico, tomando en cuenta la composición del gas (antes de cualquier tratamiento) para 3 campos de la costa caribe, el perfil de elevación de uno de los gasoductos de la costa caribe y la influencia de las condiciones climáticas en el comportamiento del gas en la tubería. Resultados: Se encontró que algunos países definen su PRH dependiendo de la región donde se transporte el gas. Las simulaciones del gasoducto seleccionado con gases pobres sin ningún tratamiento previo en las peores condiciones ambientales de la costa caribe colombiana muestran que existe una ligera condensación de líquido a $21^{\circ} \mathrm{C}$, mostrando una brecha con las regulaciones actuales (7.2 - C) en las cuales se podría proponer una cricondenterma máxima adicional para la costa caribe colombiana. Conclusiones: Se concluye que una nueva cricondenterma para climas cálidos colombianos en la regulación de trasporte actual debería estar entre $10 \mathrm{y}$ $12,8{ }^{\circ} \mathrm{C}$. La propuesta se basa en los resultados obtenidos en simulaciones y que varios de los gasoductos colombianos operan solo en regiones cálidas de Colombia

Palabras clave: Cricondenterma; tubería de gas natural, regulación colombiana, simulación. 


\section{Introduction}

Depending on the reservoir's source, raw natural gas can have different compositions. Normally, raw natural gas is composed of methane $\left(\mathrm{CH}_{4}\right)$, other light hydrocarbons from ethane to pentane $\left(\mathrm{C}_{2} \mathrm{H}_{6}\right.$ to $\left.\mathrm{C}_{5} \mathrm{H}_{12}\right)$, heavy hydrocarbons $(\mathrm{C} 6+)$, water $\left(\mathrm{H}_{2} \mathrm{O}\right)$, carbon dioxide $\left(\mathrm{CO}_{2}\right)$, hydrogen sulfide $\left(\mathrm{H}_{2} \mathrm{~S}\right)$, helium and nitrogen [1]. If the heavy hydrocarbons are not removed from the stream of the raw natural gas before its sale to a transmission company, at some point in the pipeline, these compounds begin to condense, causing corrosion issues, an increase in the pressure drop and liquid carryover in the pipeline. These situations may result in operational and integrity issues in the equipment downstream in the gas pipeline [2]. The raw natural gas can also be classified according to its liquid content measured in GPM or gallons of liquid recoverable per 1,000 standard cubic feet (MSCF) of gas (in SI, cubic meters of liquids recoverable per 100 cubic meters of gas). Based on this measure, the rich and lean terms refer to the amounts of recoverable hydrocarbons in the natural gas. A lean gas will usually contain 1 GPM or less, whereas a rich gas may contain 3 or more GPM [3].

The hydrocarbon dew point (HCDP) defines whether the natural gas stream in a pipeline at a given pressure and temperature consists of a single gas phase or two phases (gas and liquid) [4]. The highest temperature above which a liquid cannot be formed, regardless of the pressure, is called the cricondentherm [5]. As natural gas flows through a pipeline, its temperature varies depending on the ambient temperature surrounding it. To avoid hydrocarbon condensation, the natural gas temperature within the pipeline should always be higher than the HCDP. The heat transfer (between the gas inside the pipe and its surroundings) and the pressure drop define whether hydrocarbon condensation occurs. The cricondentherm is a property that depends on the gas composition, hence it indicates the level of heavy hydrocarbons (hexane and heavier) in the natural gas. It is an important quality parameter written into regulations and tariffs from producers through transmission and distribution companies to the final end users [6].

The technical specification that a country issues to regulate its natural gas transmission must represent a balance between the best performance of the gas appliances and the cost of the gas supply. If the gas specification is too narrow, it will present a barrier to the creation of an effective and efficient gas market by limiting gas sources and thereby increasing the gas processing cost. On the other hand, a broad gas specification results in increased safety risks and can lead to efficiency losses [7]. A well-balanced gas specification is one that offers the broadest possible range of natural gas parameters while maintaining safety, reliability, efficiency and compliance with environmental standards throughout the supply chain of transmission, distribution and consumption [8].

According to the 2015 Indicative Plan for Natural Gas Supply in Colombia, without the inclusion of gas supply from a regasification plant or gas imports, Colombia was expected to have a natural gas deficit of approximately 400 Million of Standard Cubic Feet per Day (MMSCFD) beginning in the second half of 2017 [9], [10]. After the 2015 report, a transitory plan was issued in November 2016 with recommendations to the Ministry of Mines and Energy about the future infrastructure and plans for implementation in the following 5 years. 
Some projects identified in this report were the Pacific regasification plant and the strengthening of the current gas transport infrastructure [11]. In addition, it is estimated that the national natural gas demand will reach an average annual growth of $2.5 \%$ between 2017 and $2031[11,10]$.

For this reason, it is necessary to explore and develop new gas fields and take full advantage of the existing ones. Although there are opportunities for new sources of gas entering the Colombian gas market (small lean gas fields, offshore gas fields, associated gas fields), the actual cricondentherm regulation acts as a barrier for several new potential lean gas fields in warm climates in the country. The cost of processing this gas to meet the regulation probably discourages the development of these fields. Making adjustments to the cricondentherm or HCDP of these lean gases (with small removal ratios of heavy hydrocarbons) is a complex and expensive process, because the technology to be implemented demands large amounts of energy and the resulting amount of heavy hydrocarbon product is not commercially viable, since in some cases, recovery of the stabilized hydrocarbon condensates is economical only for rich gases [12], [13].

The first cricondentherm limit in the Colombian regulation for natural gas pipeline transmission was established in 1999 , and the value approved was $4.4^{\circ} \mathrm{C}$. Later, in 2004 , a study [14] was carried out at some main pipelines located in the Colombian south (Centragas, Centroriente and Mariquita-Cali) and concluded that at $7.2^{\circ} \mathrm{C}$, there was no evidence of hydrocarbon condensation for that specific natural gas flowing inside that particular gas pipeline, even at its coldest parts. The 2004 study supported a modification of the regulation for natural gas transmission in Colombia, and a new cricondentherm of $7.2^{\circ} \mathrm{C}$ was establis hed at any pressure for gas pipelines all over the country [15]. This is the current HCDP limit that has been established in the Colombian regulation. It adequately fits the coldest parts of the country, but there is an opportunity to propose a different maximum limit on the cricondentherm for the Colombian Caribbean coast taking into account that $48 \%$ of the natural gas pipelines are located in these warm regions and their minimum average temperature oscillates between 21 and $23^{\circ} \mathrm{C}$ [16], [17]. Countries around the world with high climatic diversity within their territories similar to those in Colombia, such as Brazil [18], Venezuela [19] and Australia [20], [21], have different HCDP limits in their regulations depending on the region in which the gas is transported. This allows the producer to reduce its investments because the cost of processing gas and the economics of the gas supply are directly related to the limits imposed by the gas quality specifications [22].

This study aimed to propose a different maximum limit on the cricondentherm for warm climates on the Colombian Caribbean coast, following trends in current regulations in other countries. For this purpose, different countries were studied to identify the main drivers of their actual regulations. Then, a gas pipeline on the Caribbean coast of Colombia transporting two types of natural gas prior to any treatment was simulated at different ambient temperatures to identify the possibility of hydrocarbon condensation by changing the operating temperature and pressure. Conditions promoting hydrocarbon condensation in the simulation were compared to the current Colombian regulation. Finally, an interval in which a different limit for the cricondentherm for warm climates in the gas quality regulation of Colombia was proposed, taking into account that a slight modification in the gas quality 
parameters can result in considerable savings in the design and performance of a gas processing plant and transmission system.

\section{Materials and methods}

\subsection{Evaluated Gases}

The samples were taken from three Caribbean lean gas fields, and two of them were mixed in different proportions before treatment and sold as a new natural gas. In this study, the gas from one of the lean gas fields was identified as Gas A, while the mixed ones were identified as Gas B. Table 1 shows the extended chromatography results used to model the gases.

The gas condensate sample compositions were determined by a cryogenic distillation technique and gas chromatography. A portion of the single-phase sample was condensed and then it was gradually allowed to return to the ambient temperature. The evolved gas and the residual condensate were collected separately, weighed and then analyzed by gas chromatography. The compositions were then recombined mathematically to determine the wellhead fluid composition. The gas composition was measured using a "one-shot" Varian 3800 gas analyzer (Varian Inc. Palo Alto, California, USA), with GPA 2286 and 3 columns to clearly identify all of the eluted components from $\mathrm{N}_{2}, \mathrm{CO}_{2}$ and $\mathrm{C}_{1}$ through $\mathrm{C}_{11+}$. The chromatograph was calibrated using air and synthetic hydrocarbon gas with a known composition. The resultant calibration data was checked statistically against previous calibrations. The liquid compositions were measured using an HP 6890 chromatograph (Agilent Inc., Santa Clara, California, USA), which was checked twice per week with a gravimetric n-paraffin mix containing a range of pure components from $\mathrm{C}_{8}$ through $\mathrm{C}_{36}$ and a synthetic gas-oil mix (according to ASTM -D2887) with a known composition. The resultant calibration data was checked statistically against previous calibrations prior to performing analyses on unknown samples.

Extended chromatography was used because it is almost universally accepted in the oil and gas industry that compositional data at least through $\mathrm{C}_{9}$ is required for an accurate hydrocarbon dew point prediction [23]. Heavy hydrocarbons modify the cricondentherm of the gas, and small changes in the higher hydrocarbon components have a greater effect on the hydrocarbon dew point than the lower carbon number components in a typical natural gas. As a rough rule of thumb, a change in the $\mathrm{C}_{9}$ concentration of $1 \mathrm{ppm}$ can cause a $17.2^{\circ} \mathrm{C}$ change in the dew point temperature, whereas an 8 ppm change in the $\mathrm{C}_{7}$ concentration would be required to produce the same effect [24]. Thus, if the heavy hydrocarbons are not analyzed separately, the chance of under-specifying the treatment process for the recovery or removal of such hydrocarbons is very high [25].

This study used the worst case scenario for the cricondentherm of all of the possible mixtures. Fig. 1 shows the simulated phase envelope in a temperature versus pressure plot for the 
evaluated gases (Gas A and Gas B). The thermodynamic model used to simulate these gases is explained in the next section.

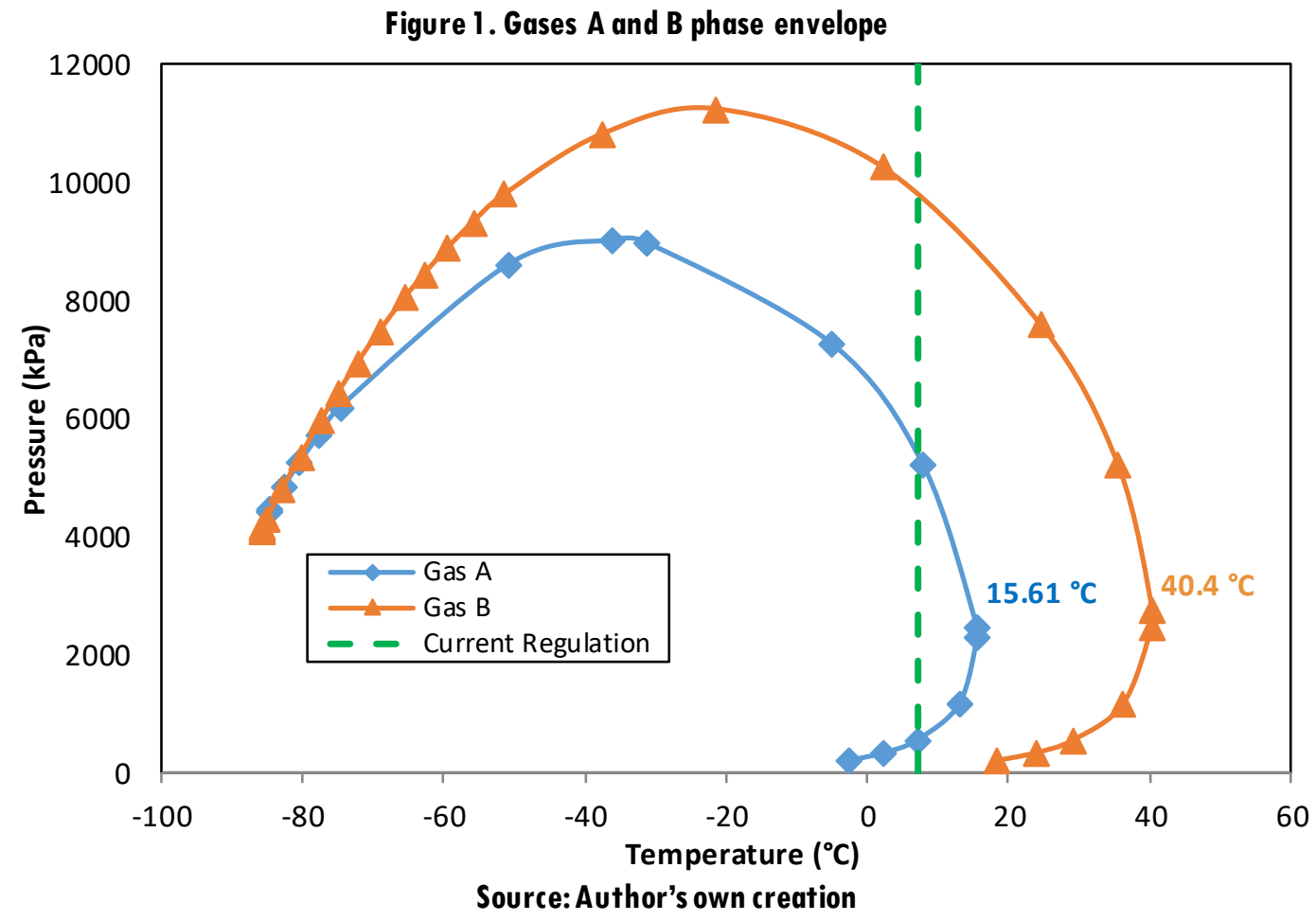

Gas A has a cricondentherm of $15.6^{\circ} \mathrm{C}$, which is close to the value in the natural gas transmission regulation. However, the temperature is above the limit, so the gas has to be treated to meet the $7.2^{\circ} \mathrm{C}$ limit. Gas B is a richer gas with a cricondentherm of $40.4^{\circ} \mathrm{C}$.

Table 1. Extended gas chromatography results for analyzed gases

\begin{tabular}{ccc}
\hline Component & $\begin{array}{c}\text { GAS A } \\
\text { Molar \% }\end{array}$ & $\begin{array}{c}\text { GAS B } \\
\text { Molar \% }\end{array}$ \\
\hline Oxygen & 0 & 0 \\
Nitrogen & 1.5295 & 0 \\
Carbon Dioxide & 0.031 & 0.6032 \\
Methane & 98.0728 & 98.9926 \\
Ethane & 0.2603 & 0.1575 \\
Propane & 0.0638 & 0.0617 \\
i-Butane & 0.016 & 0.0583 \\
n-Butane & 0.0068 & 0.0135 \\
neo-Pentane & 0.0003 & 0.0017 \\
i-Pentane & 0.005 & 0.0229 \\
n-Pentane & 0.0013 & 0.0042 \\
2,2-Dimethylbutane & 0.0001 & 0.0006 \\
\hline
\end{tabular}




\begin{tabular}{|c|c|c|}
\hline $\begin{array}{l}\text { Cyclopentane+ 2,3- } \\
\text { Dimethylbut }\end{array}$ & 0 & 0.0023 \\
\hline Isohexane & 0.0005 & 0.0026 \\
\hline 3-Methylpentane & 0.0004 & 0.0022 \\
\hline n-Hexane & 0.0003 & 0.0011 \\
\hline 2,2-Dimethylpentane & 0 & 0 \\
\hline Methylcyclopentane & 0.0006 & 0.0097 \\
\hline Isoheptane & 0.0001 & 0.0003 \\
\hline Benzene & 0.0002 & 0.0007 \\
\hline 3,3-Dimethylpentane & 0 & 0.0001 \\
\hline Cyclohexane & 0.0001 & 0.0012 \\
\hline 2,3-Dimethylpentane & 0.0003 & 0.0006 \\
\hline 3-Methylhexane & 0.0004 & 0.0013 \\
\hline $\begin{array}{l}1 \mathrm{t}, 3- \\
\text { Dimethylcyclopentane }\end{array}$ & 0.0001 & 0.0016 \\
\hline 3-Ethylpentane & 0 & 0.0014 \\
\hline $\begin{array}{c}1 \mathrm{c}, 3- \\
\text { Dimethylcyclopentane }\end{array}$ & 0.0004 & 0 \\
\hline IsoOctane & 0.0003 & 0.0044 \\
\hline n-Heptane & 0.0002 & 0.0003 \\
\hline Methylcyclohexane & 0.0006 & 0.0061 \\
\hline $\begin{array}{c}1,1,3- \\
\text { Trimethylcyclopentane }\end{array}$ & 0 & 0.0001 \\
\hline $\begin{array}{c}\text { Ethylcyclopentane }+ \\
\text { 2,5 Dimethyl }\end{array}$ & 0 & 0.0013 \\
\hline $\begin{array}{c}\text { 1t,2c,3- } \\
\text { Trimethylcyclopentane }\end{array}$ & 0 & 0.002 \\
\hline Toluene & 0.0002 & 0.0019 \\
\hline 2-Methylheptane & 0.0001 & 0.0007 \\
\hline $\begin{array}{c}1 \mathrm{t} \text {,ethylB } \\
\text { methylcyclopentane }\end{array}$ & 0 & 0.003 \\
\hline $\begin{array}{c}1 \mathrm{t}, 2- \\
\text { Dimethylcyclohexane }\end{array}$ & 0.0002 & 0.0017 \\
\hline n-Octane & 0 & 0.0003 \\
\hline $\begin{array}{c}\mathrm{t}-1,3- \\
\text { Dimethylcyclohe xane }\end{array}$ & 0 & 0.0018 \\
\hline $\begin{array}{c}1 \mathrm{c}, 4- \\
\text { Dimethylcyclohexane }\end{array}$ & 0.0002 & 0.0014 \\
\hline 2,3Dimethylheptane & 0 & 0.0013 \\
\hline o-Xilene & 0 & 0.0013 \\
\hline Ethylcyclohexane & 0.0008 & 0.0008 \\
\hline
\end{tabular}




\begin{tabular}{ccc}
\hline $1,1,3-$ & & \\
Trimethylcyclohexane & 0.0005 & 0.0061 \\
Ethylbenzene & 0.0007 & 0.0031 \\
m,p-Xilene & 0.0001 & 0.0028 \\
3-Methyloctane & 0 & 0.0023 \\
n-Nonane & 0.0002 & 0.0024 \\
Mesitilene & 0 & 0.008 \\
Decanes & 0.0016 & 0.0019 \\
Undecane & 0.0033 & 0.0016 \\
Dodecane & 0 & 0.001 \\
Tridecane+ & 0 & 0.001 \\
Paraffins C 9 & 0.0005 & 0 \\
\hline Total & $\mathbf{1 0 0}$ & $\mathbf{1 0 0}$ \\
\hline
\end{tabular}

Source: Author's own creation

\subsection{Equation of State (EOS)}

HCDP measurements were taken in the production pipeline of one of the evaluated fields at different delivery pressures to determine an EOS that represents the evaluated gases' behavior, The collected data were then compared with some of the most frequently used EOS in the oil and gas industry: Peng-Robinson (PR), generalized cubic equation of state (GCEOS), Peng-Robinson-Stryjek-Vera (PRSV), Soave-Redlich-Kwong (SRK) and SoaveRedlich-Kwong-Twu (SRK-Twu) [26]. Fig. 2 shows the behavior of each thermodynamic model in comparison with the collected data. The equations that best represent the experimental data are the PR and the GCEOS, with the average absolute deviation (AAD) of $10.35 \%$ and $16.7 \%$, respectively. In addition, several studies [27], [28], [29], [30] have demonstrated that the PR equation usually determines the behavior of hydrocarbon mixture s accurately [31], especially when the mixtures are not very close to their critical points [6].

The determination of the suitable EOS for this study is based on the mixing rules, which use a quadratic term component for molecular attraction and a linear term component for molecular repulsion [32]. The Peng-Robinson EOS was selected [33] for calculating the gas thermodynamic behavior inside the gas pipeline. 
Fig. 2 - Hydrocarbon Dew Point Measurements and EOS Adjustment Comparison

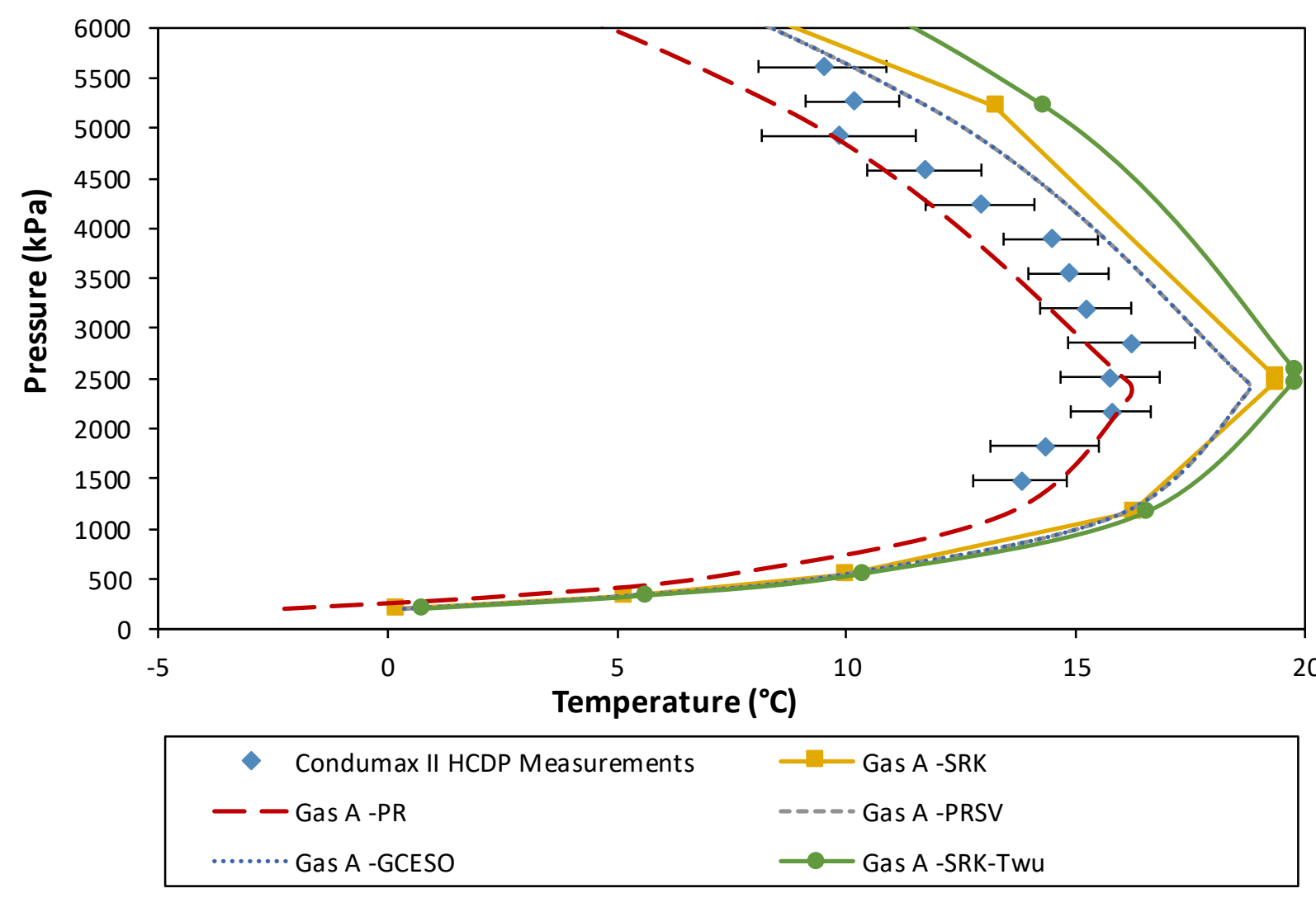

Source: Author's own creation

\subsection{Warm climate in the Colombian Caribbean coast and the evaluated gas pipeline system}

The Colombian Caribbean region is located at the northern part of the country, representing $11.6 \%$ of the $1141748 \mathrm{~km}^{2}$ that comprises the total Colombian territory, and it is mainly characterized by low altitude terrains (less than 130 m.a.s.l.) and a high mean temperature $\left(28^{\circ} \mathrm{C}\right)$. [34]. The evaluated pipeline is $450 \mathrm{~km}$ long, has a diameter of 8 in $(203 \mathrm{~mm})$, and traverses a major section of the Colombian Caribbean coast. Fig. 3 shows the location of the analyzed gas pipeline: from east to west, the pipeline starts in Plato (Magdalena) and goes up to Valledupar (Cesar); from south to north, the pipeline starts in San Roque (Cesar) and goes up to Santa Marta (Magdalena). The two pipelines have an intersection in Bosconia (Cesar). 
The highest point on the evaluated gas pipeline is located at 210 m.a.s.l (between Bosconia and Valledupar). Hence, geographic locations higher than 210 m.a.s.l (like Sierra Nevada de Santa Martha, which is also located in the Colombian Caribbean region) are not included in this study. Therefore, the proposed cricondentherm in this study is restricted to those gas pipelines located below 210 m.a.s.l.

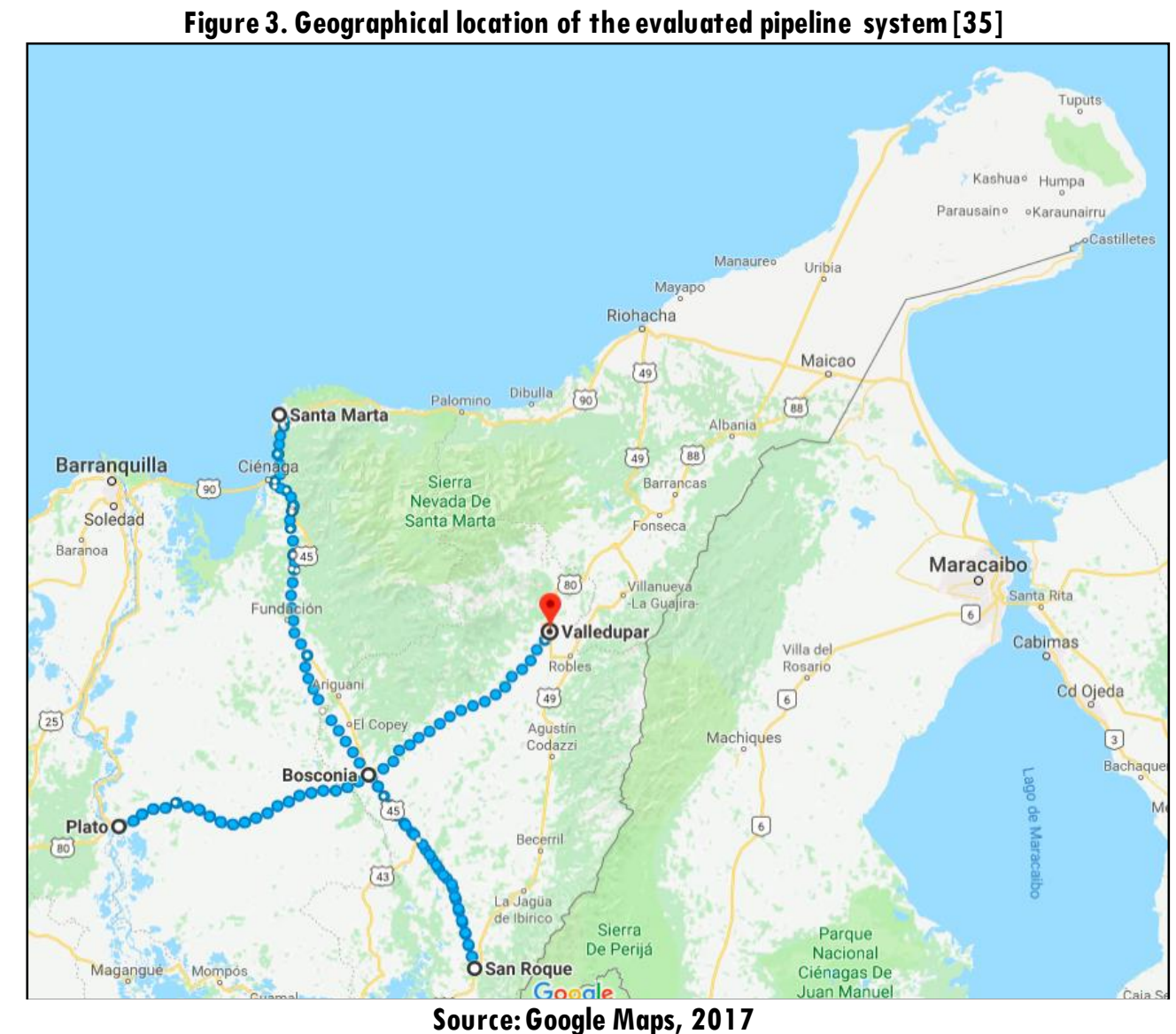

\subsection{Hydraulic modeling}

To accurately calculate the flow patterns, possible liquid hold up, and pressure gradient inside the gas pipeline system, a flow correlation is needed. Empirical and mechanistic correlations have been developed for particular sets of flow characteristics, such as Lockhart and Martinelli, Hughmark, Beggs and Brill, Taitel and Dukler, Cheremisinoff and Davis, and Oliemans [36]. According to [37], the correlation that best allows the prediction of the pressure losses and liquid hold up, and handles different flow directions, is Beggs and Brill [38]. This model was later modified to include a correction for the pressure drop calculation, a correction for the friction in rough pipelines, and a correction for multiphase conditions in pipelines with an ascending or descending slope [39]. This correlation, known as modified Beggs and Brill, was used in this study for the gas pipeline hydraulic modeling. 


\subsection{Heat transfer modeling}

To predict the temperature profile within a pipeline, the heat transfer between the natural gas and the environment should be considered. The natural gas temperature in an underground pipeline can be considered isothermal. The ambient temperature, the thermal conductivity of any given terrain and the thermal conductivity of the pipeline material have a direct impact on the heat transfer rate [40]. Table 2 shows the main parameters needed to simulate the heat transfer rate.

Table 2. Gas pipeline, soil and pipe insulation characteristics

\begin{tabular}{|c|c|c|c|c|}
\hline Section & Plato -Bosconia & $\begin{array}{l}\text { San Roque - } \\
\text { Bosconia }\end{array}$ & $\begin{array}{l}\text { Bosconia - } \\
\text { Santa Marta }\end{array}$ & $\begin{array}{l}\text { Bosconia - } \\
\text { Valledupar }\end{array}$ \\
\hline Soil Type & Moist Clay & Moist Clay & Moist Clay & Moist Clay \\
\hline $\begin{array}{c}\text { Soil Conductivity }(\mathrm{J} / \mathrm{s}- \\
\left.\mathrm{cm}-{ }^{\circ} \mathrm{C}\right)[41]\end{array}$ & 0.007493 & 0.007493 & 0.007493 & 0.007493 \\
\hline Pipeline Depth (cm) & 120 & 120 & 120 & 120 \\
\hline $\begin{array}{l}\text { Pipe Conductivity } \\
\left(\mathrm{W} / \mathrm{cm}-{ }^{\circ} \mathrm{C}\right)\end{array}$ & 0.5096 & 0.5096 & 0.5096 & 0.5096 \\
\hline Insulation Type & Urethane Foam & $\begin{array}{l}\text { Urethane } \\
\text { Foam }\end{array}$ & $\begin{array}{l}\text { Urethane } \\
\text { Foam }\end{array}$ & $\begin{array}{l}\text { Urethane } \\
\text { Foam }\end{array}$ \\
\hline $\begin{array}{l}\text { Insulation } \\
\text { Conductivity (J/s-cm- } \\
{ }^{\circ} \text { C) }\end{array}$ & $1.8 \mathrm{E}-4$ & $1.8 \mathrm{E}-4$ & $1.8 \mathrm{E}-4$ & $1.8 \mathrm{E}-4$ \\
\hline $\begin{array}{l}\text { Insulation Thickness } \\
\text { (mm) }\end{array}$ & 38 & 38 & 38 & 38 \\
\hline
\end{tabular}

Source: Author's own creation

A summary table containing the average temperatures used for the gas pipeline simulation is shown in Table 3. Usually, the gas pipeline surrounding temperature is between 28 and $29^{\circ} \mathrm{C}$; during the coldest months of the year, the temperature might descend to $21^{\circ} \mathrm{C}$, and in the warmest months, the temperature reaches almost $37^{\circ} \mathrm{C}$.

Table 3. Gas pipeline surrounding average temperature [17]

\begin{tabular}{|c|c|c|c|c|}
\hline Section & $\begin{array}{l}\text { Plato - } \\
\text { Bosconia }\end{array}$ & $\begin{array}{l}\text { San Roque - } \\
\text { Bosconia }\end{array}$ & $\begin{array}{l}\text { Bosconia - } \\
\text { Santa Marta }\end{array}$ & $\begin{array}{l}\text { Bosconia - } \\
\text { Valledupar }\end{array}$ \\
\hline $\begin{array}{l}\text { Meteorological } \\
\text { Station }\end{array}$ & $\begin{array}{l}\text { Zambrano / } \\
\text { Santa Marta }\end{array}$ & Valledupar & $\begin{array}{l}\text { Ciénaga / Zona } \\
\text { Bananera }\end{array}$ & Valledupar \\
\hline $\begin{array}{l}\text { Average T Max } \\
\left({ }^{\circ} \mathbf{C}\right)\end{array}$ & 34 & 37 & 33 & 37 \\
\hline T Mean $\left({ }^{\circ} \mathbf{C}\right)$ & 28 & 29 & 28 & 29 \\
\hline $\begin{array}{l}\text { Average T Min } \\
\left({ }^{\circ} \mathrm{C}\right)\end{array}$ & 22 & 22 & 22 & 21 \\
\hline
\end{tabular}

${ }^{6}$ The material is API 5L X42 Steel 


\subsection{Heat transfer global coefficient}

The global heat transfer coefficient combines the internal and external convective coefficients, insulation and the pipeline's own characteristics into a unique parameter that is associated directly with the heat transfer [40]. For the calculation of the heat transfer coefficient between the gas pipeline and the environment, four predictive correlations were reviewed: Petukov, Dittus, Sieder and ProFES. It was found that the first three correlations can only analyze flows in one phase, mainly turbulent flow (Reynolds number > 10000) [42], [43]. On the other hand, the ProFES correlation [44] based on the Reynolds, Prandtl and Nusselt numbers allows the evaluation of systems with two and three phases in laminar flow, taking into account the flow regime. Consequent simulations showed that the analyzed gases had a Reynolds number between 9500 and 10100. Based on this fact, the ProFES correlation was selected, as it allows adequate modeling of the heat transfer in the eventual retrograde condensation process of the gas. Retrograde behavior describes a transition from the gas phase (or liquid phase) to partial condensation (or partial vaporization) and back to the init ial phase with an isothermal change in pressure or an isobaric change in temperature. This property is particularly pronounced for mixtures that boil over a wide temperature range, such as natural gas [45].

\subsection{Gas pipeline simulation}

Hysys (version 7.3, Aspen Tech, Burlington, MA, USA, 2011) was used for the gas pipeline simulation to identify the operating conditions (pressure and temperature) under which hydrocarbon condensation might occur. Table 4 shows the three scenarios evaluated for the gas pipeline for each ambient temperature presented in Table 3. Different operational combinations among the three operating scenarios were also evaluated. The maximum and minimum operating pressures adhere to the current Colombian gas quality specifications: a maximum pressure of $8270 \mathrm{kPa}$ and the minimal pressure found in the gas pipeline.

Table 4. Evaluated Operational Cases

\begin{tabular}{llll}
\hline Scenario & $\begin{array}{l}\text { Operating } \\
\text { Pressure } \\
(\mathbf{k P a})\end{array}$ & $\begin{array}{l}\text { Operating } \\
\text { Temperature } \\
\left({ }^{\circ} \mathbf{C}\right)\end{array}$ & $\begin{array}{l}\text { Operating } \\
\text { Gas Flow } \\
(\text { MMSCFD) }\end{array}$ \\
\hline $\mathbf{1}$ & 6200 & 32 & 20 \\
$\mathbf{2}$ & 7580 & 38 & 25 \\
$\mathbf{3}$ & 8270 & 38 & 30 \\
\hline
\end{tabular}

Source: Author's own creation 


\section{Results}

\subsection{HCDP limit comparison}

Table 5 shows the HCDP limits for the gas pipeline transmission in 17 gas producing countries and the European Union with different climate conditions within their territories or near the equator. It shows that most countries establish a single HCDP for a specific pressure. However, gas quality specifications vary not only between countries but also between jurisdictions within countries. Some countries establish their HCDPs depending on the region of the country in which the gas is transported. For example, Western Australia, Brazil and Venezuela present different limits of HCDP depending on the region.

Table 5 HCDPs in different countries [16][17][18][19][20][21][46]

\begin{tabular}{|c|c|}
\hline Country & Limit $\left({ }^{\circ} \mathbf{C}\right)$ \\
\hline Argentina & -4 a $5500 \mathrm{kPa}$ abs \\
\hline Western Australia & $\begin{array}{l}\text { It varies between } 0 \text { and } 10 \text {, depending on the } \\
\text { region }\end{array}$ \\
\hline Brazil & $\begin{array}{l}\text { It varies between } 0 \text { and } 15 \text { at } 4500 \mathrm{kPa} \text {, } \\
\text { depending on the region }\end{array}$ \\
\hline Mexico & -2 at $8000 \mathrm{kPa}$ \\
\hline Peru & - \\
\hline Ecuador & -2 at $8000 \mathrm{kPa}$ \\
\hline Venezuela & $\begin{array}{l}20^{\circ} \mathrm{C} \text { difference between gas and ambient } \\
\text { temperature }\end{array}$ \\
\hline New Zealand & 2 at $5000 \mathrm{kPa}$ \\
\hline Iran & $\begin{array}{l}\text { It varies between }-10 \text { and }-5 \text {, depending on the } \\
\text { gas source }\end{array}$ \\
\hline European Union & -2 at $7000 \mathrm{kPa}$ \\
\hline Canada & $\begin{array}{l}\text { It varies between }-10 \text { and }-6.7 \text {, depending on } \\
\text { the region }\end{array}$ \\
\hline United States & $\begin{array}{l}\text { It varies between }-10 \text { and }-6.7 \text {, depending on } \\
\text { the region }\end{array}$ \\
\hline UAE & -2 at $\max .6900 \mathrm{kPa}$ \\
\hline Singapore & 12.8 at $5000 \mathrm{kPa}$ \\
\hline England & $\begin{array}{l}\text { It depends on the type of specification: }-2 \text { up } \\
\text { to } 8500 \mathrm{kPa} \text { or "Such that liquid do not } \\
\text { interfere with integrity of network or } \\
\text { appliances" }\end{array}$ \\
\hline France & -2 up to $7000 \mathrm{kPa}$ \\
\hline Germany & Ground temp at pipeline pressure \\
\hline Colombia & 7.2 at any pressure \\
\hline
\end{tabular}




\subsection{Effect of ambient temperature on the gas pressure profile}

Fig. $4 \mathrm{a}$ and $4 \mathrm{~b}$ correspond to the pressure profiles for Gas A grouped by pipeline sections: the first section going east to west, from Plato to Valledupar, and the second section going south to north, from San Roque to Santa Marta. The results for the three evaluated scenarios are similar to those of scenario 1. As before, there was no evidence of condensation in any case. In scenario 1, Gas A shows slight differences in the gas outlet pressure when the ambient temperature is modified (the greatest difference is $565 \mathrm{kPa}$ ). These differences are mainly due to changes in the gas density and viscosity [3] because there is no evidence of hydrocarbon condensation. In this case, it can be observed that the variation of the ambient temperature has little to no effect on the pressure gradient and that the only condition defining the gradient is the pipeline elevation profile. The results for the two other operational scenarios are similar to those of scenario 1.

Figure 4a. Pressure profile of Gas A at different ambient temperatures (Plato - Valledupar section)

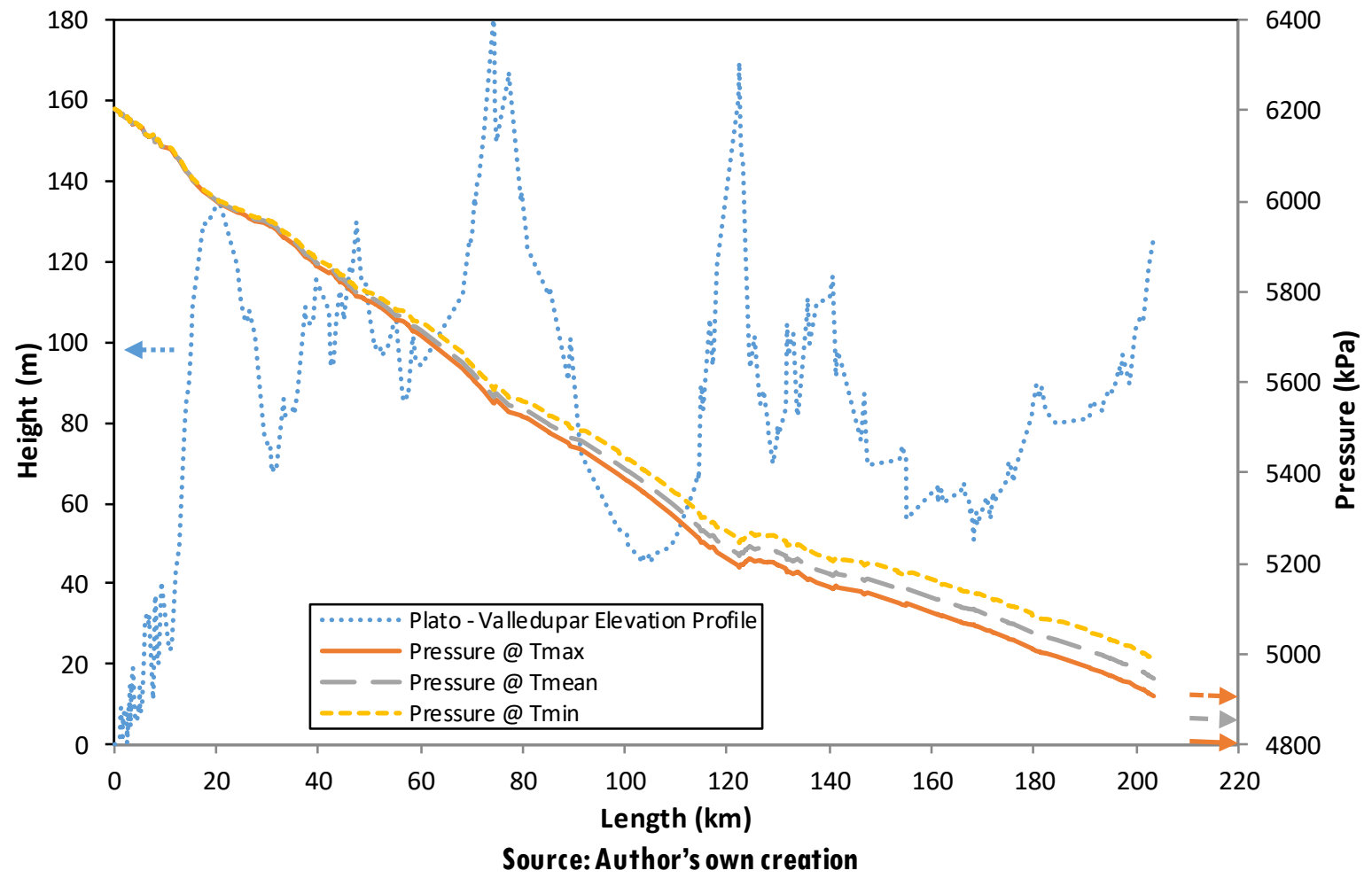


Figure 4b. Pressure profile of Gas A at different ambient temperatures (San Roque - Santa Marta section)

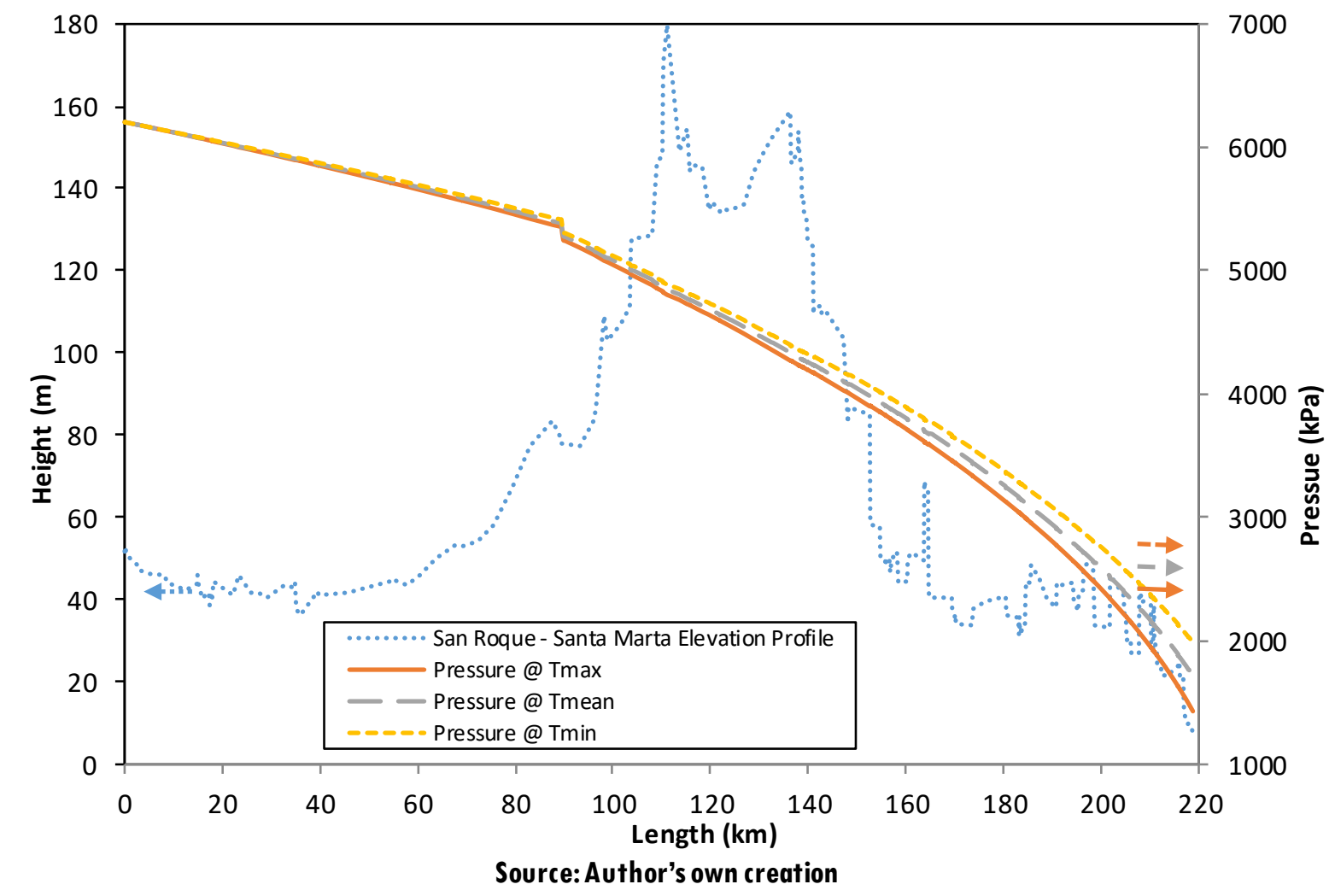

The results for Gas B are shown in Fig. 5a and 5b. A noticeable difference in the pressure profiles can be seen depending on the evaluated ambient temperature. This is due to the amount of the condensed liquid and the different gas pipeline inlet pressure requirements. For example, if the operation is carried out at the mean ambient temperature, it is not possible to have an inlet pressure below $6890 \mathrm{kPa}$, while if the operation is carried out at the maximum ambient temperature, the minimum inlet pressure required becomes $6205 \mathrm{kPa}$ (685 Pa less). It has been shown experimentally that the presence of even small quantities of liquid can have a huge effect on the pressure gradient in the gas transport [47]. A liquid buildup as low as 0.005 can result in pressure losses up to $30 \%$ compared to the pressure gradient of a pipeline transporting only gas with no liquid [48]. 
Figure $5 a$. Pressure profile of Gas B at different ambient temperatures (Plato - Valledupar section)

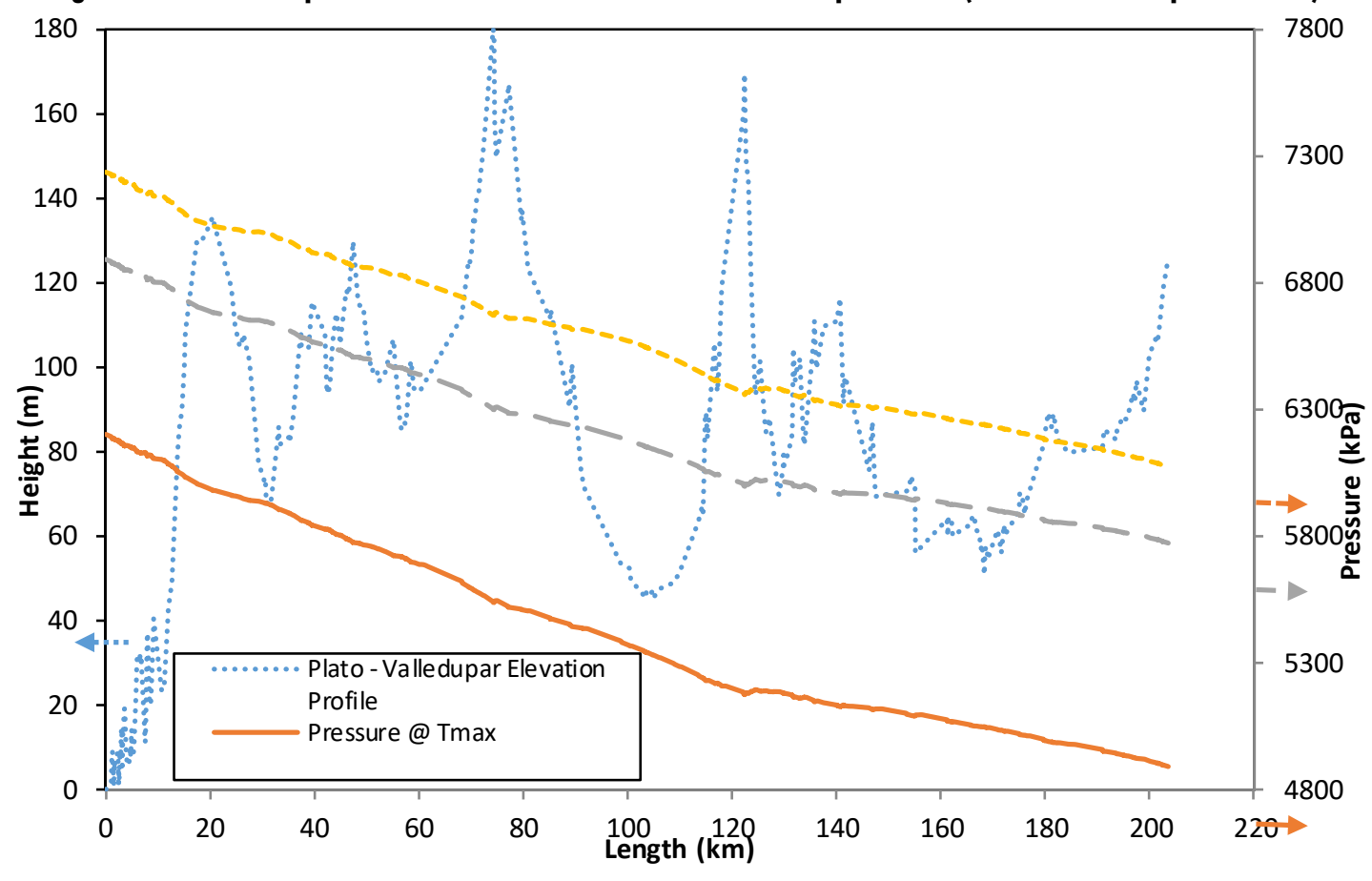

Source: Author's own creation

Figure $\mathbf{5 b}$. Pressure profiles of Gas B at different ambient temperatures (San Roque - Santa Marta section)

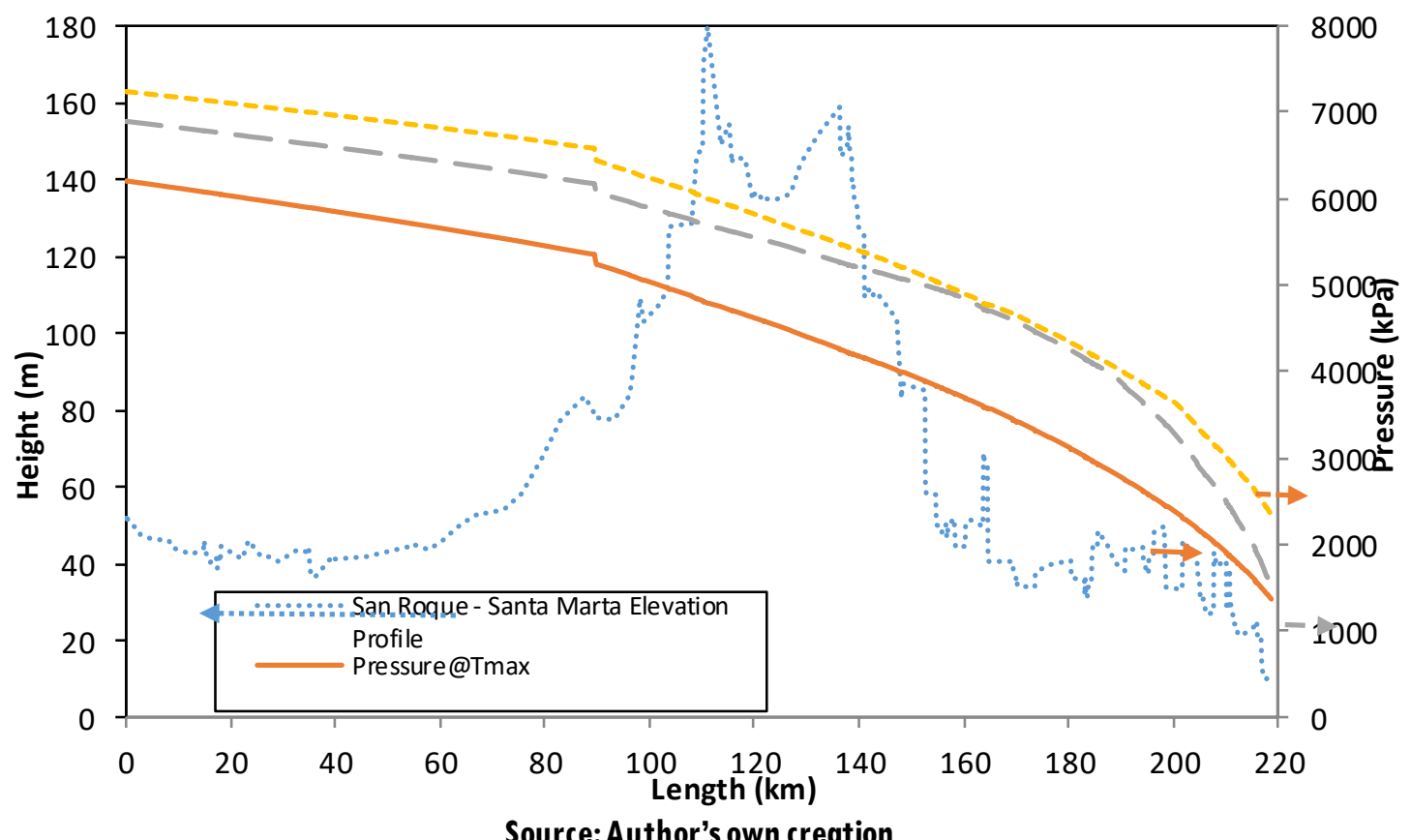


Upon reviewing the pressure gradient profiles vs. the pipeline length for Gases A and B (Fig. 6 ), increased pressure losses due to the presence of liquid in the gas pipeline are observed. For Gas A, the maximum gradient is $0.05 \mathrm{kPa} / \mathrm{m}$, while for Gas $\mathrm{B}$, the gradient is $0.12 \mathrm{kPa} / \mathrm{m}$.

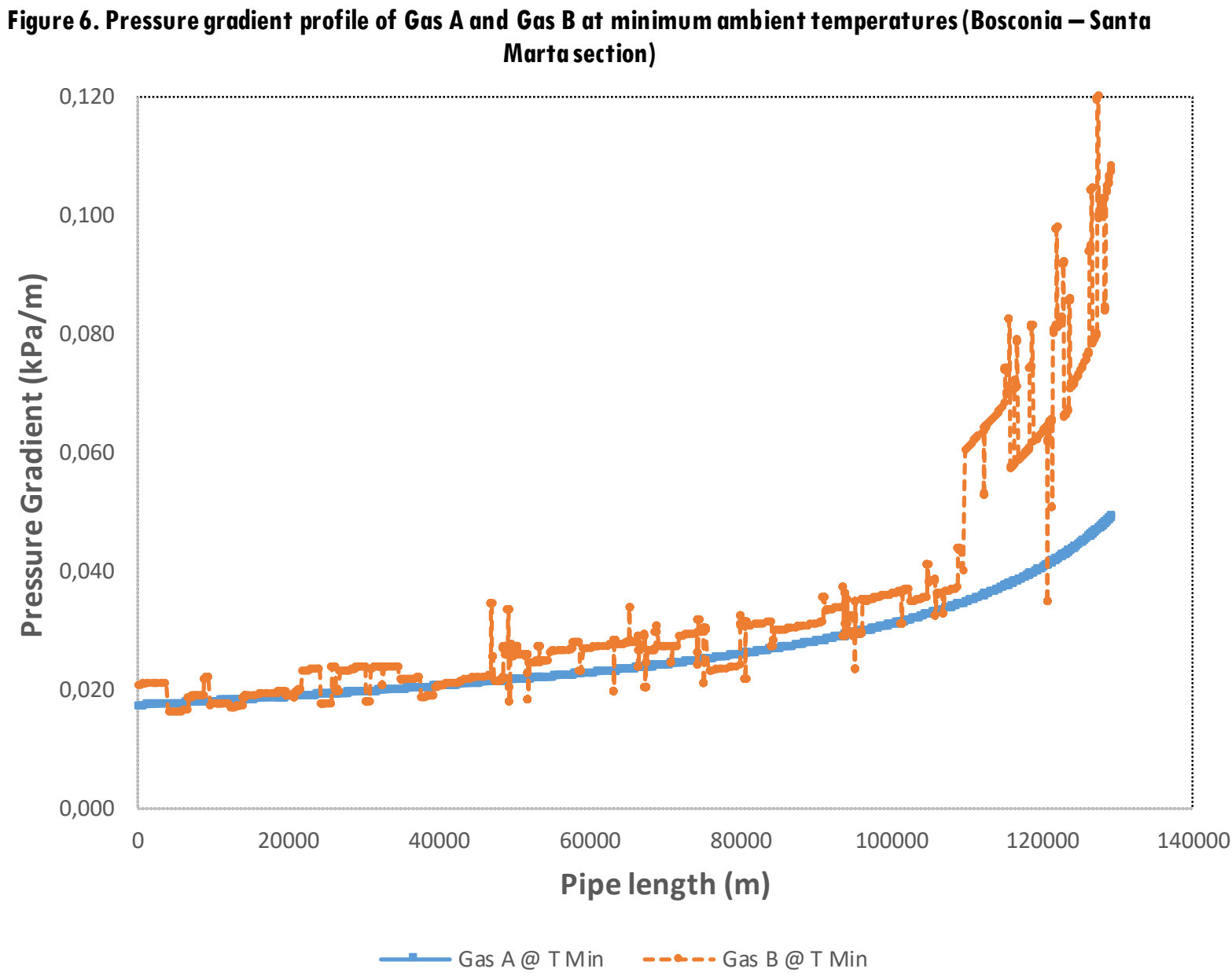

Source: Author's own creation

\subsection{Effect of the ambient temperature on the gas temperature profile}

The evaluation of the operating temperature profile in the gas pipeline relative to any variation in the ambient temperature and terrain elevation shows that for all of the evaluated scenarios for gases $\mathrm{A}$ and $\mathrm{B}$, the gas pipeline temperature rapidly equilibrates to the ambient temperature and it becomes the operating temperature, regardless of the operating pressure.

As was previously stated for Gas A, there is no evidence of liquid buildup to any degree, even at the lowest operating temperature of the gas pipeline of $21^{\circ} \mathrm{C}$, upon arrival to Santa Marta with a gradual pressure loss from 6200 to $1379 \mathrm{kPa}$ in scenario 1. For Gas B, taking 
into account its cricondentherm $\left(40.6^{\circ} \mathrm{C}\right)$, the liquid buildup is shown for all operating temperatures, with the proportion increasing as the ambient temperature decreases. The maximum quantity of condensed liquid obtained after the review of all operational scenarios for Gas B was $15.6 \mathrm{~L} / \mathrm{h}$ for the minimum ambient temperature upon arrival to Santa Marta, $21^{\circ} \mathrm{C}$.

Since in the case of Gas A, there was no liquid buildup in the gas pipeline in any scenario, a possible operating scenario where condensation might occur was sought, and 2 possibilitie s were found: a) sudden depressurization in regulating stations and b) retrograde condensation. A graphical summary of all of the evaluated gas pipeline operation points for Gas $\mathrm{A}$ is shown in Fig. 7.

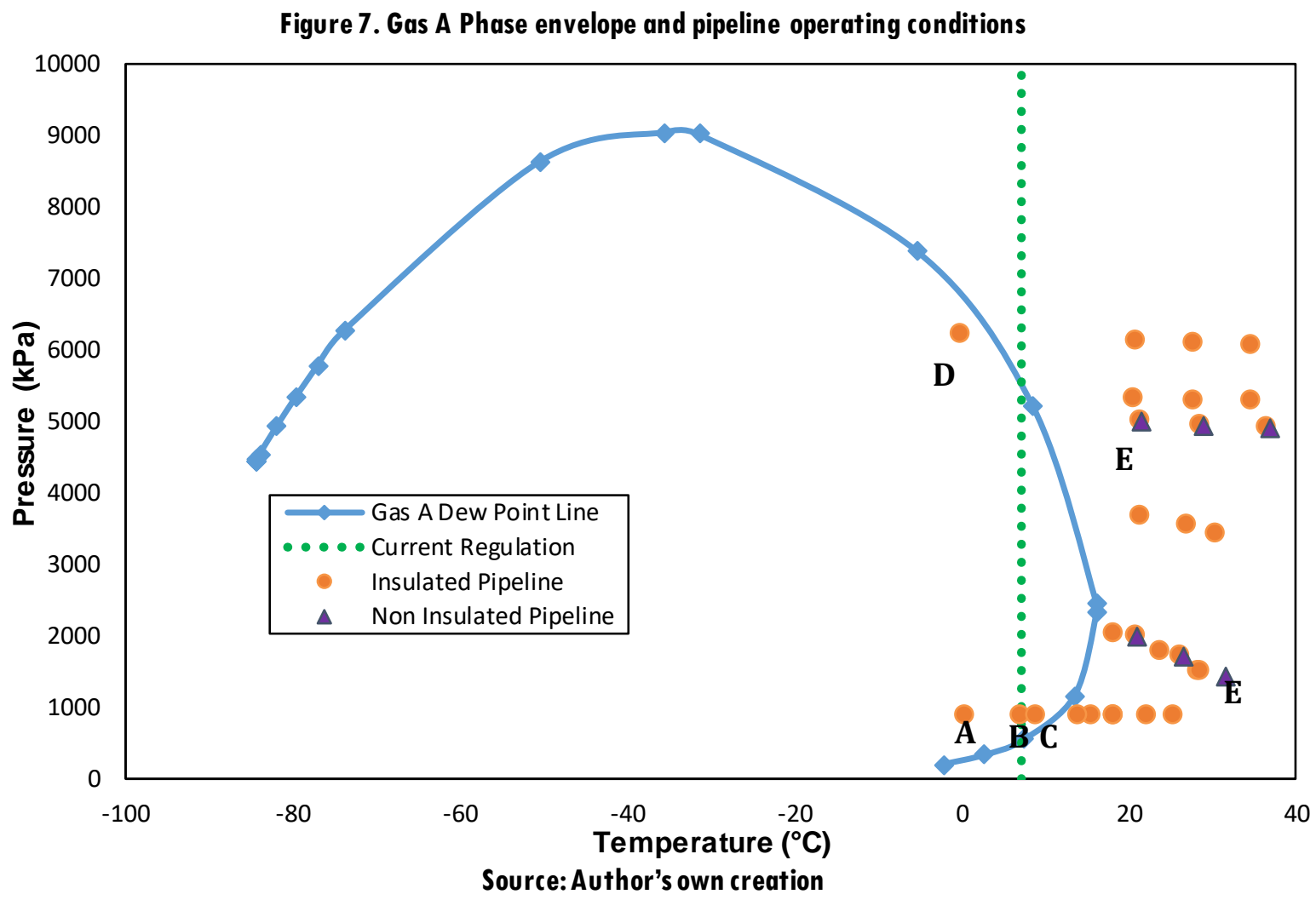

If there is any sudden depressurization, for example, from $3347 \mathrm{kPa}$ to $862 \mathrm{kPa}$, and the gas pipeline is operating at the minimum ambient temperature possible, there is a possibility of hydrocarbon condensation at the pressure regulation station $(\mathrm{A}, \mathrm{B}, \mathrm{C})$. On the other hand, if the pipeline is "packed" (meaning that there is no input or output of gas into the system) and a constant $6205 \mathrm{kPa}$ pressure is maintained, retrograde condensation might occur if the operating temperature is $0^{\circ} \mathrm{C}$ (D). The first situation can be easily avoided by installing a heater before the depressurization; the second one is very unlikely to occur, taking into account that the minimum ambient temperature on the Colombian Caribbean Coast is $21^{\circ} \mathrm{C}$ (see Table 3.). Fig. 7 also shows that from the heat transfer perspective, the difference between the insulated and noninsulated pipelines is negligible, and the gas pipeline final temperature (soil temperature) is the same for the evaluated scenarios (E). 


\section{Conclusions}

Comparing the HCDP and cricondentherm limits established in countries with a high climatic diversity within their territories similar to those seen in Colombia, it is possible to suggest a different cricondentherm limit based on the location of the gas pipeline system. This limit should not compromise the security of the existing network. According to the results obtained in the simulation from Gas A with a cricondentherm of $15.6^{\circ} \mathrm{C}$, where there was no hydrocarbon condensation, it is possible to state that an adequate cricondentherm limit for gas pipelines transiting the Colombian Caribbean coast is between 10 and $12.6^{\circ} \mathrm{C}$. The condensation phenomena that may occur at the regulation stations might be controlled through the installation of heating equipment prior to the gas expansion. It is important to state that although these reported results are on a simulation basis and a further experimental design must be made in order to confirm these findings, they are useful to provide a preliminary technical feasibility for this proposal. This newly proposed cricondentherm might also be applied in gas pipelines located in warm climates in other parts of the country, depending on the gas final user location. It is important to understand that the gas quality specification impacts competition in both the upstream and downstream markets, and hence options for the development of a uniform broad gas quality specification should be examined to develop and enhance the gas market in Colombia.

\section{Acknowledgments}

The authors are grateful to Universidad de La Sabana for the financial support of this work.

\section{References}

[1] C. A. Scholes, G. W. Stevens and S. E. Kentish, "Membrane gas separation applications in natural gas processing," Fuel, vol. 96, pp. 15-28, Jun 2012. [Online]. Available: https://doi.org/10.1016/j.fuel.2011.12.074

[2] W. Mazyan , A. Ahmadi , H. Ahmed and M. Hoorfar, "Market and technology assessment of natural gas processing: A review," JNGSE, vol. 30, pp. 487-514, Mar 2016. [Online]. Available: https://doi.org/10.1016/j.jngse.2016.02.010

[3] A. Kidnay, W. Parrish and D. G. McCartney, Fundamentals of Natural Gas Processing. Boca Raton, FL, US: CRC Press, 2011.

[4] L. Aniefiok and O. Boniface, "A new approach of splitting C6+ composition of pipeline gas for hydrocarbon dew point determination," J Petrol Explor Prod Technol, vol. 4, no. 2, p. 201-207, Jun 2014. [Online]. Available: https://doi.org/10.1007/s 13202-013-0073-y

[5] E. Skylogianni, N. Novak, V. Louli, G. Pappa, C. Boukouvalas, S. Skouras, E. Solbraa and E. Voutsas, "Measurement and prediction of dew points of six natural gases," Fluid Phase Equilibria, vol. 424, pp. 8-15, Sep 2016. [Online]. Available: https://doi.org/10.1016/j.fluid.2015.08.025

[6] D. Galatro and F. Marín, "Considerations for the Dew Point Calculation in Rich Natural Gas,"JNGSE, vol. 18, pp. 112-119, May 2014. [Online]. Available: https://doi.org/10.1016/j.jngse.2014.02.002

[7] Economic Regulation Authority, "Gas Exchangeability in Western Australia. Gas quality specifications of interconnected pipeline systems," 2007. [Online]. Available: https://www.erawa.com.au/cproot/6284/2/20071220\%20Gas\%20Exchangeability\%20in\%20Wes tern $\% 20$ Australia $\% 20$ -

$\% 20$ Gas \%20Quality\%20Specifications \%20of\%20Interconnected\%20Pipeline\%20Systems.pdf. 
[8] O. Karpash, I. Darvay and M. Karpash, "New approach to natural gas quality determination," J. Petrol. Sci. Eng., vol. 71, No. 3-4, pp. 133-137, 2010. [Online]. Available: https://doi.org/10.1016/j.petrol.2009.12.012

[9] Ministerio de Minas y Energía-UPME, "Plan Indicativo de Abastecimiento de Gas Natural," Mar., 2015. [Online]. Available: http://www1.upme.gov.co/Hidrocarburos/publicaciones/Plan_Indicativo_Gas_Natural_2015.pdf, Accessed on:Feb 4, 2016].

[10] Ministerio de Minas y Energía-UPME, "Plan transitorio de Abastecimiento de gas natural," Nov. $2016 . \quad$ [Online]. Available: http:/www1.upme.gov.co/Hidrocarburos/publicaciones/Plan_Transitorio_Abastecimiento_Gas_ Natural.pdf. , Accessed on:Dec 4, 2017.

[11] Promigas, "Informe del Sector Gas Natural 2017-Cifras 2016," 2017. [Online]. Available: http:/www.promigas.com/Es/Noticias/Documents/Informe-Sector-

Gas/Informe\%20del\%20Sector\%20Gas\%20Natural\%20Colombia\%202017.pdf , Accessed on: Dec 10, 2017.

[12] M. Díaz, C. Jiménez and C. Roa, "A novel absorption process for small-scale natural gas dew point control and dehydration,"JNGSE, vol. 29, pp. 8-15, Feb 2016. [Online]. Available: https://doi.org/10.1016/j.jngse.2016.01.016

[13] S. Sanaye and J. Mahmoudimehr, "Optimal design of a natural gas transmission network layout," ChERD, vol. 91, no. 12, pp. 2465-2476, 2013. [Online]. Available: https://doi.org/10.1016/j.cherd.2013.04.005

[14] C. A. Pineda, O. A. Arenas and N. Santos, "Evaluación del potencial de condensación de fluidos hidrocarburos en el sistema nacional de gasoductos: planteamiento de esquemas de operación adecuados," $C T \& F$, vol. 3, no. 3, pp. 191-202, 2007. [Online]. Available: http://www.s cielo.org.co/pdf/ctyf/v3n3/v3n3a13.pdf

[15] Colombia, Comisión de Regulación de Energía y Gas, Resolución 054. [Online]. Available: http://apolo.creg.gov.co/Publicac.ns f/Indice01/Resoluci\%C3\%B3n-2007-CREG054-2007

[16] Departamento de Investigaciones Económicas - Banco de la República, (1992). Colombia: Reseña de su Estructura Económica. Bogotá: Banco de la República de Colombia.

[17] IDEAM, "Sistema de Información para Colombia SIAC," 2015. [Online]. Available: http:/www.ideam.gov.co/web/ecosistemas/sistema-informacion-colombia-siac, Accessed on: Aug 1, 2015.

[18] Agência Nacional do Petróleo, Gás Natural e Biocombustíveis, Resolução ANP No. 16. [Online]. Available: http://www.scgas.com.br/uploads/editores/20100720165420.pdf., Accessed on: Jun 25, 2015.

[19] Venezuela, Ministerio del Poder Popular para la Energía y el Petróleo, Resolución No. 162, Normas Técnicas Aplicables para el Aseguramiento de la Calidad del Gas en Sistema de Transporte y Distribución

[20] Specification for General Purpose Natural Gas - Victoria Australian Standard AS 4564, 2011.

[21] Australia, Minister for Energy. (2010, Mar 27). Gas Supply (Gas Quality Specifications) Act 2009. [Online]. Available: https://www.slp.wa.gov.au/pco/prod/filestore.nsf/FileURL/mrdoc_17697.pdf/\$FILE/Gas\%20Sup ply\%20(Gas\%20Quality\%20Specifications )\%20Act $\% 202009 \% 20-020 \% 5$ B00-b 007\%5D.pdf?OpenElement

[22] P. Ziff, "Natural Gas Finding Itself Under Siege," Pipeline \& Gas Journal, pp. 32-35, 2012.

[23] D. L. George, "Development of accurate methods for predicting hydrocarbon dew points," South West Research Institute, San Antonio, TX, US, 2007. [Online]. Available: https://www.bsee.gov/sites/bsee.gov/files/tap-technical-assessment-program//534aa.pdf

[24] K. Ernst and D. Pettigrew, "Hydrocarbon Dew Point Monitoring Of Natural Gas Using FieldMounted On-Line Gas Chromatographs," Pipeline \& Gas Journal, pp. 43-45, 2005.

[25] T. Dustman, J. Drenker, D. Bergman and J. Bullin, "Analys is and prediction of hydrocarbon dew points and liquids in gas transmission lines," Digital Refining, Mar 2006. [Online]. Available: http://www.digitalrefining.com/artic le/1000437, Analys is_and_prediction of_hydrocarbon_dew_points_and_liquids_in_gas_transmission_lines.html\#.W 88tqWhKjIU

[26] M. Atilhan, S. Aparicio, S. Ejaz, J. Zhou, M. Al-Marri, J. Holste and K. Hall, "Thermodynamic characterization of deepwater natural gas mixtures with heavy hydrocarbon content at high pressures," JCT, vol. 82, pp. 134 - 142, Mar 2015. [Online]. Available: https://doi.org/10.1016/j.jct.2014.10.018

[27] S. Valiollahi, B. Kavianpour, S. Raeissi and M. Moshfeghian, "A new Peng-Robinson modification to enhance dew point estimations of natural gases," JNGSE, vol. 34, pp. 1137-1147, Aug 2016. [Online]. Available: https://doi.org/10.1016/j.jngse.2016.07.049 
[28] B. Kavianpour, A. Shariati and M. Moshfeghian, "Thermodynamic investigation and hydrate inhibition of real gas flow through orifice during depressurization." Process Saf. Environ. Prot., Vol. 92, No. 3, pp. 224-230, May 2014.

[29] M. Farzaneh-Gord, H. R. Rahbari, M. Bajelan and L. Pilehvari, "Investigation ofhydrate formation in natural gas flow through underground transmission pipeline," JNGSE, Vol. 15, pp. 27-37, Nov 2013. [Online]. Available: https://doi.org/10.1016/j.jngse.2013.09.001

[30] D. L. George, A. M. Barajas and R. C. Burkey, "The Need For Accurate Hydrocarbon Dew Point Determination," Pipeline \& Gas Journal, pp. 32-36, Sep 2005. [Online]. Available: https://naesb.org/pdf2/wgq_bps011206w1.pdf

[31] Kh. Nasrifar, O. Bolland and M. Moshfeghian, "Predicting Natural Gas Dew Points from 15 Equations of State.," Energy Fuels, Vol. 19, No. 2, pp. 561-572, Feb 2005. [Online]. Available: https://doi.org/10.1021/ef0498465

[32] A. Shariati, E. Straver, L. Florusse and C. Peters, "Experimental phase behavior study of a fivecomponent model gas condensate," Fluid Phase Equilibria, Vol. 362, pp. 147-150, Jan 2014. [Online]. Available: https://doi.org/10.1016/j.fluid.2013.09.041

[33] D-Yu. Peng and D. Robinson, "A New Two-Constant Equation of State," Ind. Eng. Chem. Fund., Vol. 15, No. 1, pp.59-64, 1976. [Online]. Available: https://doi.org/10.1021/i160057a011

[34] A. M. Roca and G. J. Perez, Geografia fisica y poblamiento en la costa Caribe colombiana, Doc. de trabajo sobre Economía Regional y Urbana No. 73. Bogotá, Colombia: BanRep-CEER, 2006. [Online]. Available: http://www.banrep.gov.co/sites/default/files/publicaciones/archivos/DTSER73.pdf

[35] Google, "Evaluated gas pipeline location in Google Maps," 2017. [Online]. Available: https://goo.gl/maps/bYEoBrU7iT12. Accessed on:Dec 10, 2017.

[36] H. Zhang and C. Sarica, "Low liquid loading gas/liquid pipe flow," JNGSE, Vol. 3, No. 2, pp.413422, May 2011. [Online]. Available: https://doi.org/10.1016/j.jngse.2011.03.001

[37] S. Akintola, J. Akpabio and M. Onuegbu, "Pressure Gradient Prediction of Multiphase Flow in Pipes," Brit. J.App. Sci. Technol., Vol. 4, No. 35, pp. 4945-4958, Dec 2014. [Online]. Available: https://doi.org/10.9734/BJAST/2014/12985

[38] D. H. Beggs and J. P. Brill, "A Study of Two-Phase Flow in Inclined Pipes," J. Petrol. Technol., Vol. 25, No. 5, pp. 607-617, May 1973. [Online]. Available: https://doi.org/10.2118/4007-PA

[39] G. A. Payne, C. M. Palmer, J. P. Brill and H. D. Beggs, "Evaluation of Inclined Pipe, Two-Phase Liquid Holdup and Pressure-Loss Correlations using Experimental Data," J. Petrol. Technol., Vol. 31, No. 9, Sep 1979. [Online]. Available: https://doi.org/10.2118/6874-PA

[40] A. Oosterkamp, J. Helgaker and T. Ytrehus, "Modelling of Natural Gas Pipe Flow with Rapid Transients-Case Study of Effect of Ambient Model," Energy Procedia, 3Vol. 64, TGTC-3 Sp. Is sue,pp. 101-110, 2015. [Online]. Available: https://doi.org/10.1016/j.egypro.2015.01.013

[41] O. Farouki, "Thermal Properties of Soil," Crrel Monograph 81-1, US Army., 1981.

[42] C. Tzanos, "Predictions of the Heat Trans fer Coefficient by Correlations and Turbulence Models," Nuclear Technol., Vol. 183, No. 1, pp. 88-100, 2013. [Online]. Available: https://doi.org/10.13182/NT13-A16994

[43] M. Makhmalbaf, "Experimental study on convective heat transfer coefficient around a vertical hexagonal rod bundle," Heat Mass Transfer, Vol. 48, pp. 1023-1029, 2012. [Online]. Available: https://link.springer.com/content/pdf/10.1007/s00231-011-0951-0.pdf

[44] Aspen Technology Inc., "Aspen HYSYS Property Packages," Aspen Process Engineering Webinar, 2006.

[45] M. E. Voulgaris, C. J. Peters and J. de Swaan Arons, "On the retrograde condensation behavior of lean natural gas," Int J Thermophys, Vol. 16, No. 3, pp. 629-642, May 1995. [Online]. Available: https://doi.org/10.1007/BF01438848

[46] BP-IGU, Guidebook to Gas Interchangeability and Gas Quality, 2011. [Online]. Available: http://www.igu.org/sites/default/files/node-page-

field_file/Guidebook $\% 20$ to $\% 20 \mathrm{Gas} \% 20$ Interchangeability $\% 20$ and $\% 20 \mathrm{Gas} \% 20 \mathrm{Qua}$ lity $\% 2 \mathrm{C} \% 20$ Augüst\%202011.pdf. Accessed:Dec 1, 2017

[47] P. Hamersma and J. Hart, "A pressure drop correlation for gas/liquid pipe flow with a small liquid holdup," Chem. Eng. Sci., Vol. 42, No. 5, pp. 1187-1196, 1987. [Online]. Available: https://doi.org/10.1016/0009-2509(87)80068-4

[48] M. Adewuni, L. Mucharan and R. Watson. Field Study and Modeling of Condensation in Gas Distribution Pipeline. Presented at Annual Technical Conference and Exhibition of the Society of Petroleum Engineers, San Antonio, TX, Oct 8-11, , 1989. 